Araştırma Makalesi / Research Article

\title{
Exploring the language assessment literacy of Turkish in-service EFL teachers
}

\author{
Türk İngilizce öğretmenlerinin dil değerlendirmesi \\ okuryazarlığı araştırması
}

\begin{abstract}
Gönderim Tarihi / Received : 05.04.2021
Kabul Tarihi / Accepted : : 28.05.2021

Doi: https://doi.org/10.31795/baunsobed.909953
\end{abstract}

\section{Sezgin BALLIDAC̆ $\check{C}^{* 1}$ Banu INAN-KARAGÜL²}

\begin{abstract}
The purpose of this study is to find out the language assessment literacy (LAL) of teachers who teach English at state elementary, middle, and high schools in Turkey. 101 teachers working in various cities participated in this study. A mixed-methods research design was employed in the study, so the data were collected through both quantitative (questionnaires) and qualitative (interviews) instruments. The data for the quantitative part of the study were collected by means of the "Teachers Questionnaire" prepared by Vogt \& Tsagari (2014) under three domains regarding language testing and assessment (LTA); classroom-focused LTA, purposes of testing and content and concepts of LTA. The data from questionnaires were analyzed via SPSS in terms of means, percentages, and frequencies to find out the training levels and needs of the respondents in language assessment. In the qualitative phase, a total of 18 teachers volunteered to take part in the interviews. The qualitative data that was gathered through semi-structured interviews were analyzed one by one in terms of their similarities and differences, and selective coding was utilized. The overall results from the questionnaires indicated that EFL teachers who work at state high, middle and elementary schools in Turkey perceived their training levels in all three domains of LTA insufficient, and they were also in need of further basic training in those domains. Furthermore, qualitative findings also supported the findings from the questionnaires by also providing insights into the reasons for participants' insufficiency of LAL levels.
\end{abstract}

Keywords: EFL, Language assessment literacy, Language testing and assessment.

\footnotetext{
"This study is a condensed summary of the master's thesis "Exploring the language assessment literacy of Turkish in-service EFL teachers" written by Sezgin Ballıdağ.

** Sorumlu Yazar / Corresponding Author

${ }^{1}$ Öğr. Gör., Yıldız Teknik Üniversitesi/ Yabancı Diller Yüksekokulu, sballidag@gmail.com, https://orcid.org/0000-0002-6402-5632

${ }^{2}$ Doç. Dr., Kocaeli Üniversitesi/ Eğitim Fakültesi/ İngiliz Dili Eğitimi Bölümü,

banu_inan@yahoo.com, https://orcid.org/0000-0001-8672-1383
} 
ÖZ: Bu çalışma Türkiye'deki ilkokul, ortaokul ve lise kademesindeki devlet okullarında çalışan İngilizce öğretmenlerinin dil değerlendirme okuryazarlığını incelemeyi hedeflemiştir. Bu çalışmaya, farklı şehirlerde çalışan 101 öğretmen katılmıştır. Çalışmada, yöntem olarak karma yöntemden yararlanılmıştır, bu yüzden veri, hem nicel (anket) hem de nitel araştırma (mülakat) araçları aracılığıyla toplanmıştır. Araştırmanın nicel bölümünün verisi Vogt ve Tsagari tarafından hazırlanan (2014) Öğretmen Anketi vasıtasıyla üç alan altında toplanmıştır; sınıf odaklı dilde ölçme ve değerlendirme, ölçmenin amaçları ve dilde ölçme ve değerlendirmenin içerik ve kavramları. Anketlerden toplanan veri, katılımcıların eğitim seviyeleri ve ihtiyaçlarını belirlemek için ortalamalar, yüzdeler ve sıklıklar bakımından SPPS aracılığıyla analiz edilmiştir. Nitel aşamada, toplam 18 öğretmen mülakatlara katılmaya gönüllü olmuştur. Yarı-yapılandırılmış mülakatlar vasıtasıyla toplanan veri benzerlik ve farklılıkları bakımından tek tek analiz edilmiş ve seçici kodlama yapılmıştır. Anketlerden elde edilen genel sonuçlar, devlet lisesi, ortaokulu ve ilkokulunda çalışan İngilizce öğretmenlerinin, yabancı dilde ölçme değerlendirmenin tüm üç alanında da eğitim seviyelerini yetersiz olarak gördüklerini ve aynı zamanda bu alanlarda temel bir eğitime ihtiyaç duyduklarını göstermiş̧tir. Ayrıca, nitel bulgular da anketlerden elde edilen veriyi, katılımcıların dil değerlendirme okuryazarlığının yetersizliğinin sebepleri konusunda fikir de vererek desteklemektedir.

Anahtar Kelimeler: Yabancı dil olarak İngilizce, Dil değerlendirme okuryazarlığı, Dilde ölçme ve değerlendirme. 


\section{GENIŞLETİLMIŞ ÖZET}

\section{Literatür taraması}

$\mathrm{Bu}$ çalışmanın amacı Türkiye'de ilkokul, ortaokul ve lise kademesindeki devlet okullarında görev yapan İngilizce öğretmenlerinin dil değerlendirme okuryazarlı̆̆ını belirlemektir. Dil değerlendirme okuryazarlığını test eden araştırmalar genellikle üç ana konuya odaklanmaktadır, bunlar, üniversitelerde verilen ölçme ve değerlendirme derslerinin yararlılığı, öğretmenlerin ölçme konusundaki bilgileri ve öğretmenlerin kendi düşüncelerine göre ölçme ile ilgili ihtiyaçları doğrultusundaki inançlarıdır. Alanda yapılan hem yurt içindeki hem de yurtdışındaki araştırmalar, İngilizce öğretmenlerinin dil değerlendirme okuryazarlığının düşük olduğunu göstermektedir. Öğretmen eğiticilerinin çoğu dil öğretimin teorik kısmına önem vermektedirler (Jeong, 2013), bu sebeple, yeni mezun olan öğretmenler ilk defa çalışmaya başladıkları zaman, öğrendikleri bu teorik bilgiyi kullanamamaktadırlar. Bu gerçeğe rağmen, üniversitelerde okutulan dilde ölçme ve değerlendirme derslerine gerekli önem verilmemektedir (Jin, 2010; Orr, 2010; Hatipoğlu, 2015). Türkiye'de yapılan dil değerlendirme okuryazarlı̆̆ 1 konusundaki araştırmaların çoğu, üniversite öğrencileri ve devlet üniversitesinde çalışan öğretim görevlileri üzerinde yapılmıştır; devlet ilköğretim, orta öğretim ve lise kademesinde çalışan İngilizce öğretmenlerini hedef alan kısıtlı sayıda çalışma bulunmaktadır. $\mathrm{Bu}$ kademelerde çalışan öğretmenlerin, çoğunlukla uyguladıkları sınavları kendilerinin hazırladıkları da düşünüldüğünde, bu hedef kitlenin dilde ölçme ve değerlendirme okuryazarlığı önem arz etmektedir. Bu yüzden, bu çalışma, devlet ilkokul, orta okul ve lise kademesinde çalışan İngilizce öğretmenlerinin dilde ölçme ve değerlendirme konusunda algılanan ve ihtiyaç duyulan eğitim seviyesini belirleyerek alandaki bu boşluğu kapatmayı hedeflemektedir.

\section{Yöntem}

Bu çalışma şu sorulara cevap bulmayı hedeflemekledir;

Devlet ilkokulu, ortaokulu ve liselerinde çalışan İngilizce öğretmenlerinin dil değerlendirme okuryazarlığı konusunda algılanan eğitim seviyesi nedir?

Devlet ilkokulu, ortaokulu ve liselerinde çalışan İngilizce öğretmenleri, dil değerlendirme ile ilgili ne kadar eğitime ihtiyaç duyduğunu düşünüyorlar?

Bu çalışmadaki veri, 2019-2020 eğitim öğretim yılında toplanmıştır. Bu çalışmada karma yöntem kullanılmıştır, dolayısıyla hem nitel (mülakat) hem de nicel (anket) yöntemler vasıtasıyla veri toplanmıştır. Veri toplama süreçleri açısından, tüm veri tek seferde toplandığı için, bu araştırma bir enine-kesit çalışmasıdır. Bu araştırmanın nicel kısmına, Türkiye'nin farklı illerinde 
çeşitli devlet ilkokulu, ortaokulu ve lisesinde çalışan 101 İngilizce öğretmeni katılmıştır. Örneklem uygun örnekleme ile seçilmiştir. Araştırmada, nicel veri Vogt ve Tsagari'nin (2014) tasarladığı Öğretmen Anketi ile toplanmıştır. Toplam 36 öğesi bulunan anket üç alt kısımdan oluşmaktadır; sınıf odaklı dilde ölçme ve değerlendirme, dilde ölçme ve değerlendirmenin içerik ve kavramları ve ölçmenin amaçları. Ankete katılan örneklemin eğitim seviyelerini belirlemek için, ortalama, yüzde ve sıklık açısından veri SPSS ile analiz edilmiştir. Araştırmanın nitel kısmını oluşturan mülakatlara ise ankete katılan öğretmenlerin 18'i gönüllü olmuştur. Anketlerden toplanan veri benzerlik ve farklılıkları açısından ayrı ayrı incelenmiş ve seçici kodlama yapılmıştır. Katılımcıların kaygı düzeylerini düşürmek ve daha kişisel bilgi vermelerini sağlamak adına, mülakat soruları ayrıca Türkçe olarak da sunulmuştur.

\section{Bulgular ve tartışma}

Katılımcıların algılanan sınıf odaklı dilde ölçme ve değerlendirme seviyeleri incelendiğinde, portföy hariç diğer alanlarda 1-2 günlük bir eğitim aldıklarını düşündükleri bulunmuştur. En yüksek ortalama değer öğrencilere geri dönüt verme alanında bulunurken, en düşük değer portföy kullanımı alanında kaydedilmiştir. Ölçmenin amaçları alanındaki algılanan en yüksek değer ise ne öğretilmesi/öğrenilmesi gerektiğini ortaya koyma alanında bulunmuştur. Bu bölümde katılımcıların en az eğitim aldıklarını düşündükleri alan ise öğrencilere sertifika vermek olarak bulunmuştur. Dilde ölçme ve değerlendirmenin kavram ve içerikleri konusunda ise, katılımcılar en çok eğitimi dilbilgisi ve kelime ölçme ve değerlendirme alanında aldıklarını düşünürken, toplanan veri kültürel öğeleri ölçme ve değerlendirme konusunda en az eğitimi aldıklarını düşündüklerini ortaya koymuştur.

Dilde ölçme ve değerlendirme alanında katılımcıların ne kadar daha eğitime ihtiyaç duydukları ile ilgili toplanan veri şunları ortaya koymuştur. Sınıf odaklı eğitim alanında en yüksek eğitime portföy kullanımında ihtiyaç vardır. Katılımcılar en az eğitime ders kitaplarından hazır metinleri kullanmak alanında ihtiyaç duyduklarını düşünmektedirler. Ölçme ve değerlendirmenin amaçları ile ilgili en fazla eğitime ihtiyaç duyulduğu düşünülen alan öğrencilere sertifika vermek olarak bulunurken en az eğitim ihtiyacı not verme alanında saptanmıştır. Ölçme ve değerlendirmenin kapsam ve içerikleri konusunda ise, katılımcılar en çok eğitime kültürel öğeleri test etmek alanında ihtiyaç duyduklarını düşündükleri bulunurken, en az eğitime dilbilgisi ve kelime ölçme alanında ihtiyaç duyguları ortaya konmuştur.

Son olarak, mülakatlardan toplanan verilere göre üniversitelerde verilen okul deneyimi derslerinin, staj okullarındaki sınırlı zaman ve staj okullarındaki 
öğretmenlerin stajyerlere yaklaşımı gibi kısıtlamalar nedeniyle faydalı olmadığı ortaya çıkmıştır. Katılımcılara, mezun olduklarında dilde ölme ve değerlendirme konusunda hazır olup olmadıkları sorulduğunda, büyük çoğunluğu hazır olmadığını ifade etmiştir. Diğer önemli bulgu ise, klasik ölçme yöntemlerinin yanı sıra, portföy gibi alternatif ölçme ve değerlendirme yöntemleri çoğu öğretmen tarafından kullanmaktadır.

\section{Sonuç ve öneriler}

Türkiye'nin farklı illerinde farklı ilkokul, ortaokul ve liselerde çalışan 101 İngilizce öğretmeni ile yapılan bu çalışma, öğretmenlerin dil değerlendirme okuryazarlı̆̆ııı belirlemeyi hedeflemektedir. Araştırmanın sonuçları, katılımcıların sınıf odaklı dilde ölçme ve değerlendirme, ölçmenin amaçları ve dilde ölçme ve değerlendirmenin içerik ve kavramları alt başlıklarının tümünde yetersiz bir ölçme değerlendirme bilgisine sahip olduklarını düşündüklerini ortaya koymuştur. Diğer araştırma sorusunun cevabı olarak ise katılımcılar yine yukarıdaki tüm alt başlıklarda temel bir eğitime ihtiyaçları olduğunu düşünmektedirler. Yapılan mülakatlar ise, bu yetersiz eğitim seviyesinin sebeplerine 1ş1k tutar niteliktedir. Örneğin, öğretmenler, mesleğe atılmadan önceki tek şansları olan okul deneyimi derslerinden verim alamadıklarını, üstüne üstük üniversitede altıkları ölçme ve değerlendirme derslerinin ülke gerçeklerini gözeterek hazırlanmadığını ifade etmektedirler. Ayrıca, araştırmanın nicel kısmında en az eğitim alındığı düşünülen ve en çok eğitim ihtiyacı olduğu belirtilen portföylerin mülakatlarda çoğu öğretmen tarafından kullanıldı̆̆ı ifade edilmiştir. Bu durumda portföylerin olması gerektiği gibi kullanılıp kullanılmadığının da araştırılmasında ve bu alanda öğretmenlere hizmet içi eğitim verilmesinde fayda görülmektedir. Son olarak, mülakatlardan edinilen bulgular, öğretmenlerin sahip olduğu ölçme ve değerlendirme becerilerinin çoğunu, okullarda birlikte çalıştıkları meslektaşlarından aldıklarını ortaya koymuştur.

Bu bulgular ışı̆̆ında, eğitim fakültelerindeki ölçme ve değerlendirme derslerin ve okul deneyimi dersinin yürütülmesinin yeniden düzenlenmesi gerektiği söylenilebilir. 


\section{Introduction}

Assessment is an indispensable part of teaching because it helps teachers reflect on their teaching; in other words, it guides teachers to improve the way they teach so as to achieve the course objectives. In order to highlight the significance of the relationship between teaching and assessment, DiRanna et al. (2008) argue that "assessment and instruction are two sides of the same coin" (p. 22). Assessment, which occurs consciously or unconsciously (Brown, 2003), is a continuing process. Various definitions of the term have been suggested in the literature. To illustrate, Thomas (2004) defines the term as collecting data to make decisions. As the knowledge of teachers on assessment issues became even more significant, in 1990 the National Council on Measurement in Education, The American Federation of Teachers, and the National Education Association came up with a framework regarding the standards of an assessment literate teacher. The movement towards professionalism in teaching, Stiggings (1991) coined a new term, assessment literacy (Hereafter AL), and it is 'sine qua non for a proficient educator today" (Popham, 2009). Mertler \& Campbell (2005) suggested a definition of AL as "an individual's understandings of the fundamental assessment concepts and procedures deemed likely to influence educational decisions" (p. 265). Developing the professional knowledge of the teachers has attracted attention for many years (Tellez \& Mosqueda, 2015); hence, in the field of language testing and assessment, there is a move towards professionalism (Farhady, 2019). This progress in raising knowledge of teachers regarding test-related activities created a new term, language assessment literacy (hereafter, LAL). Several definitions of the term can be found in the literature. According to O'Loughlin (2013), it includes a variety of skills which are needed in producing and interpreting test scores as well as evaluating the test results by taking functions of assessment in education and society into consideration. Phil \& Harding (2013) also use the term as a collection of competencies which help individuals understand, evaluate and sometimes compose language tests of themselves as well as analyzing them.

LAL has gained importance in the language teaching and learning field, and the research that seeks to provide a definition of the term and how it can be developed productively has increased (Lam, 2015). The studies conducted to examine the LAL of in-service or pre-service teachers focus on three basic categories; the potency of the assessment courses at universities, how much teachers know about assessment, and teachers perceived beliefs and needs in assessment-related issues. To start with, notwithstanding its importance, an inadequate amount of research has been conducted to find out about the efficiency of English language testing and evaluation (ELTE) courses taught at 
universities. The course content is far-reaching, yet what should be included in ELTE courses is an important issue that teachers and administrators deal with (Berger, 2012). The majority of teacher trainers give priority to theoretical aspects of assessing the languages (Jeong, 2013); therefore, when pre-service teachers start teaching in real classrooms, they may not use their theoretical knowledge they gain at universities. It was found out by much research conducted on the effectiveness of ELTE courses that the participant teachers require more training regarding language assessment (Volante \& Fazio, 2007; Hatipoğlu, 2010). Undeterred by these facts, the ELTE courses offered at universities have received lacking attention (Jin, 2010; Orr, 2010; Hatipoğlu, 2015).

Another concern of the researchers in the field has been the extent of the teachers' knowledge regarding assessment issues. In order to find out the LAL of the teachers, a considerable amount of literature has been published (Köksal, 2004; Alderson, 2005; Sarıçoban, 2011; Fulcher, 2012; Tsagari \& Vogt, 2017; Sarıyıld1z, 2018). The results from the research mentioned revealed that teachers had underdeveloped LAL levels. Besides trying to find out the LAL levels of teachers by asking teachers assessment-related questions of evaluating the exams they produced, the researchers also investigated the participants' perceived assessment literacy levels. It was revealed by various studies (Hasselgreen et al., 2004; Ölmezer-Öztürk \& Aydın, 2019) that the respondents needed more training on assessment. Although the majority of research revealed inadequate levels of perceived knowledge, there are studies such as Shim (2009), which report that the participants believed they were trained about assessment.

There are also studies that have been conducted on LAL in the Turkish setting (Hatipoğlu, 2010; Büyükkarc1, 2016; Mede \& Atay, 2017; Ölmezer-Öztürk \& Aydın, 2019; Şahin, 2019), but conducting further research is suggested by the researchers due to the limitations they possess.

\section{Statement of the problem}

When it comes to evaluating students, teachers are one of the most significant factors (Vogt \& Tsagari, 2014); hence, educating teachers has started to receive more attention (Farhady, 2019). However, the research conducted on LAL of teachers indicated that LAL of teachers is not sufficient (Jannati, 2015; Semiz \& Odabaş, 2016; Xu \& Brown, 2017). In order to investigate the LAL of teachers in Turkey, some studies have been conducted, too; however, they have limitations. To name them, they had either small number of the respondents (Yetkin, 2015; Tamerer, 2019), or they were carried at universities in Turkey (Mede \& Atay, 2017; Öz \& Atay, 2017; Ölmezer-Öztürk, 2018; Yastıbaş \& Takkaç, 2018). 


\section{Significance of the study}

Although some research has been conducted in order to figure out the LAL of teachers in the Turkish context with pre-service teachers (Sarıyıldız, 2018; Tamerer, 2019) and teachers working at universities (Mede \& Atay, 2017; Ölmezer-Öztürk \& Aydın, 2019), teachers who work at state schools received very little attention. Therefore, the purpose of this study is to add to the relatively new research area by examining the LAL of teachers who work under the umbrella of the Ministry of Education in Turkey. This study offers some significant insights into the field of LAL and curriculum developers at universities. The participant teachers will also have a chance to reflect on their assessment knowledge and choices.

\section{Research questions}

The present study aims to investigate;

1. the perceived level of training that English teachers who work at state high, middle, and elementary schools in Turkey regarding language assessment

2. how much training regarding language assessment the English teachers who work at state high, middle, and elementary schools in Turkey believe they need

\section{Methodology}

\section{Research design}

In this study, a mixed-methods design was utilized because combining quantitative and qualitative instruments contributes to the understanding of the research problem than using any of these methods alone (Creswell, 2012). In terms of data collection process, because all the data were collected at once, the present research adopts a cross-sectional design.

\section{Participants}

In this current study, the data were collected in the 2019-2020 academic year. 101 teachers who work at various state elementary, middle, and high schools participated in the quantitative part of this study, and 18 teachers volunteered to take part in the interview part. Convenience sampling was utilized in order to collect the data.

The respondents in this study are from 26 different cities in Turkey. Table 1 and Table 2 illustrate the profile of the participants for the quantitative part and qualitative part, respectively. 
Exploring the language assessment literacy of Turkish in-service EFL teachers

Table 1: Participants' profile ( $\mathrm{N}=101)$

\begin{tabular}{llcc}
\hline \multirow{3}{*}{ Gender } & & $\mathrm{N}$ & $\%$ \\
\hline \multirow{5}{*}{ Years of Experience } & Male & 38 & 37.6 \\
& Female & 63 & 62.4 \\
& $2-1$ & 2 & 2 \\
& $6-10$ & 6 & 5.9 \\
& $11-15$ & 25 & 24.8 \\
Graduated BA Program & More than 15 years & 26 & 41.6 \\
& English Language Te- & 87 & 25.7 \\
& Nohing (ELT) & 14 & 86.1 \\
& Non-ELT & 79 & 13.9 \\
& BA & 17 & 78.2 \\
& MA & 5 & 16.8 \\
& PhD & 14 & 5.0 \\
& Elementary School & 37 & 13.9 \\
& Middle School & 50 & 36.6 \\
& High School & & 49.5 \\
\hline
\end{tabular}

Table 2: Interviewed participants' profile $(\mathrm{N}=18)$

\begin{tabular}{llcc}
\hline & & $\mathrm{N}$ & $\%$ \\
\hline Gender & Male & 10 & 55.6 \\
\multirow{3}{*}{ Years of Experience } & Female & 8 & 44.4 \\
& $2-5$ & 1 & 5.6 \\
& $6-10$ & 5 & 27.8 \\
\multirow{5}{*}{ Highest Qualification } & $11-15$ & 9 & 50 \\
\multirow{3}{*}{ School Level } & More than 15 years & 3 & 16.7 \\
& BA & 16 & 88.9 \\
& MA & 2 & 11.1 \\
& Elementary School & 4 & 22.2 \\
& Middle School & 8 & 44.4 \\
& High School & 6 & 33.3 \\
\hline
\end{tabular}

\section{Data collection instruments}

The major data collection tool was Teachers' Questionnaire by Vogt \& Tsagari (2014). The questionnaire included 4 sub-parts. The first part inquired about the demographic information of the respondents. In the following three parts, there were items about classroom-focused LTA, purposes of testing 
and content and concepts of LTA. The participants needed to rate their both perceived training levels and how much training they need in each sub-part. In order to have more in-depth, reliable data, interviews were also administered with 18 of the respondents to the quantitative part of the study since they are great data collection tools due to their concern about the identities, experiences and beliefs of participants (Talmy \& Richards, 2010). The interview questions were also presented in Turkish to help the respondents stress-free during the interviews, and therefore, provide more personal data.

\section{Results}

\section{The perceived training level of the participants}

In order to answer the first research question, all the quantitative data were analyzed through SPSS descriptive statistics. The findings from three subparts regarding the perceived training levels of the participants are displayed in Table 3, Table 4, and Table 5.

Table 3: Perceived training levels of participants in classroom-focused LTA $(\mathrm{N}=101)$

\begin{tabular}{|c|c|c|c|c|c|c|}
\hline & $\mathrm{N}$ & Mean & $\mathrm{SD}$ & 0 & 1 & 2 \\
\hline Preparing classroom tests & 101 & 1.36 & .687 & 12 & 41 & 48 \\
\hline $\begin{array}{l}\text { Using ready-made tests from textbook } \\
\text { packages or from other sources }\end{array}$ & 101 & 1.36 & .672 & 11 & 43 & 47 \\
\hline $\begin{array}{l}\text { Giving feedback to students based on } \\
\text { information from tests/assessments }\end{array}$ & 101 & 1.55 & .608 & 6 & 33 & 62 \\
\hline Using self-or peer-assessment & 101 & 1.34 & .667 & 11 & 45 & 45 \\
\hline $\begin{array}{l}\text { Using informal, continuous, non-test type } \\
\text { of assessment }\end{array}$ & 101 & 1.15 & .713 & 19 & 48 & 34 \\
\hline $\begin{array}{l}\text { Using the European Language Portfolio, an } \\
\text { adaptation of it or some other portfolio }\end{array}$ & 101 & .86 & .775 & 38 & 39 & 24 \\
\hline
\end{tabular}

$0=$ Not, at all, 1= A little (1-2 days), 2= More advanced

Table 3 illustrates what teachers think about the training they received in terms of classroom-focused LTA. As can be seen in Table 3, the participants perceive that they received a little more than 1-2 days of training in all fields except for using portfolios. The highest mean value was found for "giving feedback" $(M=1.55, S D=.608)$, which showed that the respondents thought they had the highest training in this area. However, the participants believed that they received the least training in "using the European Language Portfolio" $(M=.86$, $S D=.775)$; 38 of the participants expressed that they had no training in this field. 
Table 4: Perceived training levels of participants regarding purposes of testing $(\mathrm{N}=101)$

\begin{tabular}{lcccccc}
\hline & N & Mean & SD & 0 & 1 & 2 \\
\hline Giving grades & 101 & 1.47 & .672 & 10 & 34 & 57 \\
Finding out what needs to be taught/learned & 101 & 1.49 & .642 & 8 & 36 & 57 \\
$\begin{array}{l}\text { Placing students onto courses, programs etc } \\
\begin{array}{l}\text { Awarding students final certificates (from } \\
\text { school/program: local, regional or national }\end{array}\end{array}$ & 101 & 1.12 & .739 & 22 & 45 & 34 \\
level) & 101 & .98 & .735 & 28 & 47 & 26 \\
\hline
\end{tabular}

$0=$ Not, at all, $1=$ A little (1-2 days), 2= More advanced

As shown in Table 4, the participants in the present study have the highest mean value in "finding out what needs to be taught/learned" ( $M=1.49, S D=.642)$, indicating that the teachers who work at state elementary, middle and high schools in Turkey hold the idea that they got the most training in finding out their students' needs. Giving grades, with slightly lower mean value $(M=1.47)$ is another field the participants thought they received more than a little training. Awarding final certificates, however, received the lowest mean value $(M=.98$, $S D=.735$ ) because the majority of the respondents expressed that they received a little or no training in this field.

Table 5: Perceived training levels of participants regarding content and concepts of LTA $(\mathrm{N}=101)$

\begin{tabular}{lcccccc}
\hline & $\mathrm{N}$ & Mean & SD & 0 & 1 & 2 \\
\hline $\begin{array}{l}\text { 1. Testing and assessing } \\
\text { Receptive skills (reading/listening) }\end{array}$ & 101 & 1.39 & .648 & 9 & 44 & 48 \\
$\quad$ Productive skills (speaking/writing) & 101 & 1.39 & .663 & 10 & 42 & 49 \\
$\begin{array}{l}\text { Microlinguistic aspects } \\
\text { (grammar/vocabulary) }\end{array}$ & 101 & 1.41 & .710 & 13 & 34 & 54 \\
$\quad$ Integrated language skills & 101 & 1.28 & .709 & 15 & 43 & 43 \\
Aspects of culture & 101 & 1.08 & .744 & 24 & 45 & 32 \\
$\begin{array}{l}\text { 2. Establishing reliability of tests/assessment } \\
\text { 3. Establishing validity of tests/assessment }\end{array}$ & 101 & 1.32 & .692 & 13 & 43 & 45 \\
4. Using statistics to study the quality of tests/ & 101 & 1.33 & .694 & 13 & 42 & 46 \\
assessment & 101 & 1.21 & .697 & 16 & 48 & 37 \\
\hline
\end{tabular}

$0=$ Not, at all, 1= A little (1-2 days), 2=More advanced

In the last sub-part of the questionnaire, the participants had to rate items regarding the content and concepts of language testing and assessment. As displayed in the table, it was found that all the participants believe that they received at least 1-2 days of training in all fields. Based on the findings in Table 5, the highest mean score was observed in "testing and assessing 
microlinguistic aspects (grammar/vocabulary)" $(M=1.41, S D=.710)$. To put it another way, the majority of the respondents (53.5\%) stated that they received advanced training in this field. We can also understand that the perceived level of the participants' training on testing and assessing the receptive and productive skills are the same $(M=1.39)$. Another important finding to note is that testing and assessing the aspects of culture is the field that respondents felt the weakest about $(M=1.08, S D=.744)$.

\section{The perceived needs of the participants}

The second part of the questionnaire comprised of items in order to uncover the training needs of English teachers who work at state high, middle, and elementary schools in Turkey. Table 6 displays the findings regarding the training needs of the respondents in classroom-focused LTA.

Table 6: Participants' perceived training needs regarding classroom-focused LTA $(\mathrm{N}=101)$

\begin{tabular}{|c|c|c|c|c|c|c|}
\hline & $\mathrm{N}$ & Mean & SD & 0 & 1 & 2 \\
\hline Preparing classroom tests & 101 & .88 & .816 & 40 & 33 & 28 \\
\hline $\begin{array}{l}\text { Using ready-made tests from textbook } \\
\text { packages or from other sources }\end{array}$ & 101 & .70 & .794 & 51 & 29 & 21 \\
\hline $\begin{array}{l}\text { Giving feedback to students based on } \\
\text { information from tests/assessments }\end{array}$ & 101 & .85 & .792 & 40 & 36 & 25 \\
\hline Using self-or peer-assessment & 101 & .99 & .794 & 32 & 38 & 31 \\
\hline $\begin{array}{l}\text { Using informal, continuous, non-test } \\
\text { type of assessment }\end{array}$ & 101 & .95 & .753 & 31 & 44 & 26 \\
\hline $\begin{array}{l}\text { Using the European Language Portfolio, } \\
\text { an adaptation of it or some other } \\
\text { portfolio }\end{array}$ & 101 & 1.12 & .765 & 24 & 41 & 36 \\
\hline
\end{tabular}

$0=$ None, $1=$ Yes, basic training, $2=$ Yes, more advanced training

As can be seen from Table 6, the participants' needs varied across different items. Among all the items, the participants needed the highest training in "using the European Language Portfolio" $(M=1.12, S D=.765)$. With a closer mean value, "using self-or peer-assessment is another field on which the participants reported a need for further training $(M=.99, S D=.794)$. Lastly, "using ready-made tests" was the field in which the participants reported the lowest need for extra training $(M=.70, S D=.794)$. 
Table 7: Perceived training needs of participants in purposes of testing $(\mathrm{N}=101)$

\begin{tabular}{lcccccc}
\hline & N & Mean & SD & 0 & 1 & 2 \\
\hline Giving grades & 101 & .77 & .768 & 45 & 34 & 22 \\
Finding out what needs to be taught/learned & 101 & .86 & .800 & 40 & 35 & 26 \\
$\begin{array}{l}\text { Placing students onto courses, programs etc } \\
\begin{array}{l}\text { Awarding students final certificates (from } \\
\text { school/program: local, regional or national }\end{array}\end{array}$ & 101 & 1.01 & .755 & 28 & 44 & 29 \\
level) & 101 & 1.12 & .711 & 20 & 49 & 32 \\
\hline
\end{tabular}

$0=$ None, $1=$ Yes, basic training, 2= Yes, more advanced training

As displayed in Table 7, the participants needed the highest training for "awarding students final certificates" $(M=1.12, S D=.711)$. They also reported a basic need for "placing students onto courses, programs etc." $(M=1.01$, $S D=.755)$. On the other hand, they expressed they did not even a basic training for "finding out what needs to be taught/learned" and "giving grades" $(M=.86$, and $M=.77$, respectively).

Table 8: Participants' perceived training needs regarding content and concepts of LTA $(\mathrm{N}=101)$

\begin{tabular}{lcccccc}
\hline & $\mathrm{N}$ & Mean & $\mathrm{SD}$ & 0 & 1 & 2 \\
\hline $\begin{array}{l}\text { 1. Testing and assessing } \\
\quad \text { Receptive skills (reading/listening) }\end{array}$ & 101 & .90 & .819 & 39 & 33 & 29 \\
$\quad$ Productive skills (speaking/writing) & 101 & .93 & .816 & 37 & 34 & 30 \\
$\quad$ Microlinguistic aspects & 101 & .82 & .817 & 44 & 31 & 26 \\
$\quad$ grammar/vocabulary) & 101 & .95 & .792 & 34 & 38 & 29 \\
$\quad$ Integrated language skills & 101 & 1.06 & .732 & 24 & 47 & 30 \\
$\begin{array}{l}\text { Aspects of culture } \\
\text { 2. Establishing reliability of tests/ }\end{array}$ & 101 & 1.00 & .800 & 32 & 37 & 32 \\
$\quad$ assessment & 101 & .97 & .768 & 31 & 42 & 28 \\
$\begin{array}{l}\text { 3. Establishing validity of tests/assessment } \\
\text { 4. Using statistics to study the quality of }\end{array}$ & 101 & 1.04 & .774 & 28 & 41 & 32 \\
\hline tests/assessment & & & & & & \\
\hline
\end{tabular}

$0=$ None, $1=$ Yes, basic training, $2=$ Yes, more advanced training

As displayed in Table 8, the most advanced training was needed in the field of testing and assessing aspects of culture $(M=1.06, S D=.732)$, which was followed by using statistics. $(M=1.04, S D=.774)$. Another important finding was that the participants believed that they needed the least help in testing and assessing grammar and vocabulary $(M=.82, S D=.817)$. As for testing assessing receptive $(M=.90, S D=.819)$ and productive skills $(M=.93, S D=.816)$, it was found out that the participants expressed more slightly more need for productive skills assessment. 
In order to get more detailed information regarding the needs and perceptions of the respondents about LAL, written interviews were conducted with 18 of the teachers who filled out the questionnaire. The analysis of the first question revealed that the school experience courses the pre-service teachers had at universities were not very fruitful due to various reasons like the limited time the pre-service teachers had at practicum schools, the advisory teachers' unwillingness to involve them in assessment procedures. In this vein, the following comments were made:

"Our advisory teacher at the practicum school to which we were assigned to did not involve us in the assessment process; hence, we had no chance to turn our theoretical knowledge into practice."

"... since we had a limited amount of time, the school experience course did not help us put what we learned into practice."

In the second question, the participants were inquired about their readiness to assess their learners and how they developed themselves to overcome the difficulties they faced. The comments of the interviewees revealed that the majority of them felt inadequate in terms of assessing language learning when they graduated from universities; therefore, they learned this skill as the time passes thanks to their colleagues as one interviewee put:

"I did not feel prepared to assess my learners. When I experienced difficulty, I asked for help from my colleagues, or I searched online

Another interviewee criticized the ELTE education at universities as it does not correspond to the realities of real-life by saying:

"I did not feel ready for assessment because the education offered at the universities does not fit the realities of our country."

The interviewee's willingness to participate in professional development activities after finishing university was another focus of the interview. Only two of the 18 interviewees stated that they took part in any training related to language testing and assessment. The use of SPSS, alternative assessment, and preparing rubrics were among the topics the interviewees wished to have training on. The answers of the interviewees also revealed that they made use of both traditional and alternative assessment tools to assess their learners. Written exams and quizzes were among the most mentioned traditional assessment tools, while as alternative assessment tools, they mainly used portfolios, peer-assessment, and presentations. In this vein, one of the interviewees made the following comment: 
"... in addition to traditional ways, I ask my learners to give presentations about the days topic. After the presentation, they first reflect on their own presentations, and then they reflect on their peers' presentation. Also, they collect everything in our portfolio, and I get them when the semester is over."

As a reason why they could not make use of alternative assessment methods, the following comment was made:

"I know about alternative assessment, but I have never used any of them. Our time to teach the courses is insufficient; we teach 5 hours in the $9^{\text {th }}$ grade and 2 hours in the others. If we use alternative assessment tools, we may not cover what we have to teach in the curriculum."

As can be understood from the comments made by the interviewees, school experience courses do not create an atmosphere for the in-service teachers to practice their assessment skills, and ELTE courses are not believed to provide the pre-service teachers with the necessary assessment knowledge since the majority of the participants do not feel ready for language assessment in the classroom. Furthermore, alternative assessment tools are not used due to lack of time, or they are used without having proper training on how to use them.

\section{Discussion}

This paper sought to explore the LAL of the English teachers who work at state schools in various cities in Turkey with a focus on their perceived level of training and further need for extra training. Their perceived level of training and how much extra training they need was investigated under 3 domains.

The first research question of the study aimed to explore the perceived training level of the participants in classroom-focused LTA, purposes of testing, and content and concepts of LTA. The findings revealed that the LAL of the respondents for all three domains was insufficient. This finding supports previous research by Mede \& Atay (2017), Sariyildiz (2018) and Tamerer (2019). Another crucial finding of the study is that the participants did not even believe that they had basic training in alternative assessment tools such as portfolios. This finding can be explained by the fact that Turkey is an exam-oriented country, so teachers are inclined to make use of summative assessment tools. Besides using portfolios, awarding final certificates received the second lowest mean score. A possible reason behind this might be that in the Ministry of Education, the students are not assigned certificates; therefore, this is not paid enough attention to ELTE courses.

The findings from the questionnaire about the training needs of the respondents revealed that they needed training in all three domains with various degrees. 
This overall finding of how much need for further training the participants perceive is in line with many of the previous studies (Hasselgreen et al., 2004; Vogt \& Tsagari, 2014; Jannati, 2015; Lam, 2015; Büyükkarc1, 2016; Semiz \& Odabaş, 2016; Mede \& Atay, 2017; Xu \& Brown, 2017; Ölmezer-Öztürk \& Aydın, 2019). When individual items are considered, it is crucial to note that some items are also in line with the previous part of the questionnaire. To illustrate, it was found out that the respondents believed they had the least training in "using portfolios," and they expressed in the second part that they need the highest training in this field. Moreover, testing and assessing grammar and vocabulary was also found to be the field the participants felt the most knowledgeable about. It seems possible that this result is due to the importance we attach to the teaching of grammar and vocabulary in Turkey.

The analysis of the qualitative data provided insights into the insufficient LAL of respondents. To start with, almost all of the interviewees stated that the school experience course did not give them a chance to practice their theoretical knowledge on assessment due to some constraints. Considering the possible facilitative effect of the school experience course thanks to being observed by peers and advisory teachers, pre-service teachers lose a rare chance. It can be concluded from the comments made by interviewees that practicum schools do not provide pre-service teachers with the necessary practice before they step into actual classrooms. Another important finding from interviews is that even though all participants believe that they need training in all domains with varying degrees, they did not participate in professional development courses. A possible explanation of this could be the workload of teachers when we consider the comment by one of the interviewees about the insufficient number of teaching hours. Furthermore, the data from the qualitative part of the study revealed a strong network among teachers who work at state schools in Turkey, which was also suggested by Jin (2010). The participants seemed to benefit from more experienced colleagues despite the claimed insufficiency of ELTE courses at universities. Finally, it is crucial to note that teachers who work at state schools in Turkey should be provided in-service training in alternative assessment tools, especially portfolios. Even though they reported that they needed the highest training in using portfolios, and they think they had the least training in using them, the interview results showed that portfolios are among the most used assessment tools.

\section{Conclusion}

This study investigates the language assessment literacy (LAL) of teachers who work at state schools in Turkey through a survey and an interview. The results 
indicated that the participants believe that they were not trained enough in language assessment, and they also reported a further basic training in all domains in the questionnaire.

The present results are significant for both the Ministry of Education and the Council for Higher Education in Turkey due to the insufficiency of school experience courses and ELTE courses offered at universities. Some standards for the school experience courses should be formalized in terms of the responsibilities of advisory teachers and the minimum amount of teaching practice time. Furthermore, the content of ELTE courses should be revised so as to equip the pre-service teachers with more assessment knowledge and practice. Lastly, the teachers working at state schools should be given as much in-service training on language assessment as possible to raise their LAL.

\section{References}

Alderson, J. C. (2005). Diagnosing foreign language proficiency: the interface between learning and assessment. London: Continuum.

Berger, A. (2012). Creating language assessment literacy: A model for teacher education. In J.I. Hüttner, B. Mehlmauer-Larcher, S. Reichl and B. Schiftner (Eds.), theory and practice in EFL teacher education: bridging the gap (pp. 57-82). Bristol: Multilingual Matters.

Brown, H. D. (2003). Language assessment: principles and classroom practices. Pearson Education.

Büyükkarcı, K. (2016). Identifying the areas for English language teacher development: a study of assessment literacy. Pegem Ĕgitim ve Öğretim Dergisi, 6(3), 333-346. http://dx.doi.org/10.14527/pegegog.2016.017

Creswell, J. W. (2012). Educational research: planning, conducting, and evaluating quantitative and qualitative research. Boston: Pearson Education.

DiRanna, K., Osmundson, E., Topps, J., Barakos, L., Gearhart, M., Cerwin, K., Carnahan, D. \& Strang, C. (2008). Assessment-centered teaching: a reflective practice. Thousand Oaks, CA: Corwin Press.

Farhady, H. (2019). A Cross-contextual perspective on EFL teachers' assessment knowledge. EDU7, 8(10), 1-19.

Fulcher, G. (2012). Assessment literacy for the language classroom. Language Assessment Quarterly, 9(2), 113-132.

Hasselgreen, A., Carlsen, C. \& Helness, H. (2004). European survey of language testing and assessment needs. Part one: general findings. Retrieved from http://www.ealta.eu.org/resources.htm. 
Hatipoğlu, C. (2010). Summative evaluation of an English language testing and evaluation course for future English language teachers in Turkey. English Language Teacher Education and Development (ELTED) Journal, 13, 40-51.

Hatipoğlu, C. (2015). English language testing and evaluation (ELTE) training in Turkey: expectations and needs of pre-service English Language Teachers. ELT Research Journal, 4 (2), 111-128.

Jannati, S. (2015). ELT Teachers' language assessment literacy: perceptions and practices. The International Journal of Research in Teacher Education, 6(2), 26-37.

Jeong, H. (2013). Defining assessment literacy: is it different for language testers and non-language testers? Language Testing, 30 (3), 345-362.

Jin, Y. (2010). The place of language testing and assessment in the professional preparation of foreign language teachers in China. Language Testing, 27 (4), 555-584.

Köksal, D. (2004). Assessing teachers" testing skills in ELT and enhancing their professional development through distance learning on the net. Turkish Online Journal of Distance Education (TOJDE), 5(1), 1-11.

Lam, R. (2015). Language assessment training in Hong Kong: implications for language assessment literacy. Language Testing, 32(2), 169-197.

Mede, E. \& Atay, D. (2017). English language teachers' assessment literacy: the Turkish context. Dil Dergisi, 168 (1), 1-5.

Mertler, C. A., \& Campbell, C. (2005). Measuring teachers' knowledge \& application of classroom assessment concepts: development of the "assessment literacy inventory". Online Submission.

O'Loughlin, K. (2013). Developing the assessment literacy of university proficiency test users. Language Testing, 30 (3), 363-380.

Orr, M. (2010). Evaluating the testing course in a MA in ELT. English Language Teacher Education and Development (ELTED), 13, 4-14.

Ölmezer-Öztürk, E. (2018). Developing and validating language assessment knowledge scale (LAKS) and exploring the assessment knowledge of EFL teachers. [Doctoral dissertation], Anadolu University.

Ölmezer-Öztürk, E. \& Aydın, B. (2019). Investigating language assessment knowledge of EFL teachers. Hacettepe University Journal of Education, 34(3), 602-620. doi:10.16986/HUJE.2018043465 
Öz, S. \& Atay, D. (2017). Turkish EFL instructors' in-class language assessment literacy perceptions and practices. ELT Research Journal, 6(1), 25-44.

Pill, J., \& Harding, L. (2013). Defining the language assessment literacy gap: evidence from a parliamentary inquiry. Language Testing, 30(3), 381-402.

Popham, W. J. (2009). Assessment literacy for teachers: faddish or fundamental? Theory into Practice, 48, 4-11.

Sarıçoban, A. (2011). A study on the English language teachers" preparation of tests. Hacettepe University Journal of Education, 41, 398-410.

Sariyıldız, G. (2018). A Study into language assessment literacy of preservice English as a foreign language teachers in Turkish context. [Master's thesis], Hacettepe University.

Semiz, Ö. \& Odabaş, K. (2016, June). Turkish EFL teachers' familiarity of and perceived needs for language testing and assessment literacy. Proceeding of the 3rd international linguistics and language studies conference, İstanbul, Turkey. Retrieved from https://www.academia.edu/34827097/Turkish_ EFL_Teachers_Familiarity_of_and_Perceived_Needs_for_Language_ Testing_and_Assesment_Literacy

Shim, K. N. (2009). An Investigation into teachers' perceptions of classroom-based assessment of English as a foreign language in Korean primary education. [Doctoral dissertation], University of Exeter.

Şahin, S. (2019). An analysis of English language testing and evaluation course in English language teacher education programs in Turkey: developing language assessment literacy of pre-service EFL teachers. [Doctoral dissertation], Middle East Technical University.

Talmy, S. \& Richards, K. (2010). Theorizing qualitative research interviews in applied linguistics. Applied linguistics, 32(1), 1-5.

Tamerer, R. (2019). An investigation of Turkish pre-service EFL teachers' language assessment literacy. [Master's thesis], Kocaeli University.

Téllez, K., \& Mosqueda, E. (2015). Developing Teachers' knowledge and skills at the intersection of English language learners and language assessment. ReviewofResearch in Education, 39, 87-121. doi: 10.3102/0091732X14554552

The American Federation of Teachers, the National Council on Measurement in Education, and the National Education Association (1990). The standards for teacher competence in the educational assessment of students. Retrieved from http://buros.org/standards-teacher-competence-educationalassessment-students. 
Thomas, J., Allman, C. \& Beech, M. (2004). Assessment for the diverse classroom: a handbook for teachers. Tallahassee, FL: Florida Department of Education, Bureau of Exceptional Education and Student Services. Retrieved from http://www.fldoe.org/ese/pdf/assess_diverse.pdf.

Tsagari, D. \& Vogt, K. (2017). Assessment literacy of foreign language teachers around Europe: research, challenges and future prospects. Papers in Language Testing and Assessment, 6(1), 41-63.

Vogt, K. \& Tsagari, D. (2014). Assessment literacy of foreign language teachers: findings of a European study. Language Assessment Quarterly, 11(4), 374392.

Volante, L. \& Fazio, X. (2007). Exploring teacher candidates' assessment literacy: implications for teacher education reform and professional development. Canadian Journal of Education, 30(3), 749-770.

Xu, Y. \& Brown, G. T. L. (2017). University English teacher assessment literacy: a survey-test report from China. Papers in Language Testing and Assessment, 6(1), 133-158.

Yastıbaş, A. E. \& Takkaç, M. (2018). Understanding language assessment literacy: developing language assessments. Journal of Language and Linguistic Studies, 14(1), 178-193.

Yetkin, C. (2015). An investigation on ELT teacher candidates' assessment literacy. [Master's thesis], Cag University.

\section{Ethical approval}

This study has been approved by the social sciences and humanities ethic committee of Kocaeli University with 21783 number and on 10/03/2020.

\section{Contribution rate of researchers}

$1^{\text {st }}$ author contributed $60 \%, 2^{\text {nd }}$ author contributed $40 \%$ to the study.

\section{Conflict of interest}

As the authors of the research, we state that we have no statement of interest / conflict. 